\title{
VALIDASI METODE ANALISA TOTAL FLAVONOID CONTENT MENGGUNAKAN SPECTROFOTOMETER UV/VIS JURUSAN TEKNIK KIMIA DI POLITEKNIK NEGERI MALANG
}

\author{
Rilla Agustina, Lia Agustin, Slamet Priyadi \\ Jurusan Teknik Kimia, Politeknik Negeri Malang \\ rilla_raihan@yahoo.com, 2 link_deus@yahoo.com, 3 slamtpry@gmail.com \\ (Artikel diterima: Oktober 2019, direvisi: September 2019, diterima untuk terbit: Januari 2020)
}

\begin{abstract}
Abstrak - Suatu pengembangan metode analisis diperlukan untuk mengurangi oksidan atau radikal bebas. Oksidan dapat menimbulkan kerusakan sel, menjadi penyebab atau mendasari berbagai keadaan patologik, dan ikut berperan dalam proses penuaan (aging). Flavonoid serupa dengan antioksidan, yang memiliki beragam manfaat untuk tubuh Anda, seperti dapat memperbaiki sel yang rusak akibat radikal bebas. Suplemen flavonoid juga diduga bisa mengurangi risiko kanker, hipertensi, dan diabetes. Pengujian terhadap kandungan Flavonoid Total metode AlCl3 menggunakan Spectrofotometer UV/Vis sangatlah perlu untuk di validasi. Perlunya validasi metode tersebut adalah untuk menentukan apakah seluruh tahap pengujian telah memenuhi standar yang ditetapkan. Hasil uji yang akurat adalah pencerminan dari pelaksanaan yang baik dari seluruh tahapan pengujian, maka: validasi metode dilakukan dengan cara menguji linieritas, presisi, akurasi, sampai LOD dan LOQ. Hasil penelitian menunjukkan linierisasi baik dengan nilai koefisien kolerasi (r) 0,9955, persen perolehan kembali sebesar 99,89\%, batas deteksi sebesar $1,37 \mathrm{ppm}$ dan batas kuantitas sebesar 0,516 ppm. Berdasarkan hasil penelitian tersebut, metode Total Flavonoid Content metode $\mathrm{AlCl} 3$ menggunakan spektrofotometri UV/Vis telah memenuhi standar validasi dan dikatakan valid.
\end{abstract}

Kata kunci: Validasi Metode, Total Flavonoid Content, AlCl3, Spectrofotometer UV/Vis.

\section{Pendahuluan}

Radikal bebas sering dikaitkan dengan berbagai peristiwa fisiologis seperti peradangan, penuaan, dan penyebab kanker (Bhaigyabati dkk., 2011). Radikal bebas (free radical) adalah atom atau molekul yang mempunyai elektron tidak berpasangan, terbentuk sebagai hasil antara (intermediet) dalam suatu reaksi organik melalui proses homolisis dari ikatan kovalen. Karena reaktivitasnya, senyawa radikal bebas akan segera mungkin menyerang komponen seluler yang berada disekelilingnya, baik berupa senyawa lipid, lipoprotein, protein, karbohidrat, RNA, maupun DNA. Akibat lebih jauh dari reaktivitas radikal bebas adalah terjadinya kerusakan struktur maupun fungsi sel (Winarsi, 2007).

Untuk menghindari dampak negatif dari radikal bebas maka diperlukan antioksidan. Antioksidan merupakan senyawa yang dapat mendonorkan proton kepada senyawa radikal bebas, sehingga tidak terjadi reaksi lebih lanjut yang berbahaya (Amin et al., 2006., Sandhar et al., 2011). Flavonoid merupakan salah satu senyawa antioksidan golongan fenolik alam yang terbesar dan terdapat dalam semua tumbuhan (Dyah dkk., 2014). Jumlah kandungan total senyawa flavonoid dilakukan analisis kuantitatif yaitu dengan metode pereaksi $\mathrm{AlCl} 3$ secara spektrofotometri UV-Vis dan kadarnya dinyatakan sebagai \% Quercetin Equivalent (QE).

Perlunya validasi metode untuk menentukan apakah seluruh tahap pengujian telah memenuhi standar yang ditetapkan. Hasil uji yang akurat adalah pencerminan dari pelaksanaan yang baik dari seluruh tahapan pengujian, maka : validasi metode dilakukan dengan cara menguji akurasi hasil analisis yang bersangkutan (Tahid \& Julia Kantasubrata, 2017).

Validasi ulang perlu dilakukan meskipun validasi sebelumnya menghasilkan data yang sesuai dengan kriteria penerimaan, karena metode yang dinyatakan valid pada kondisi tertentu belum tentu valid pada kondisi lain karena peralatan dan pereaksi yang digunakan, analisis yang mengerjakan dan sebagainya. Parameter validasi yang ditetapkan pada penelitian ini antara lain: Limit of detection (LOD), Limit of Quantitation (LOQ), linearitas, Presisi, dan akurasi (Alwi, 2017)

\section{Tinjauan Pustaka}

Validasi diartikan sebagai suatu tindakan pembuktian dengan cara yang sesuai bahwa tiap bahan, proses, prosedur, kegiatan, sistem, perlengkapan atau mekanisme yang digunakan dalam produksi dan pengawasan akan senantiasa mencapai hasil yang diinginkan.

Suatu metode analisis harus divalidasi untuk melakukan verifikasi bahwa parameter-parameter kinerja cukup mampu untuk mengatasi problem analisis, karenanya suatu metode harus divalidasi ketika (Alwi, 2017):

a. Metode baru dikembangkan untuk mengatasi problem analisis tertentu

b. Metode yang sudah baku direvisi untuk menyesuaikan perkembangan atau karena munculnya suatu problem yang mengarahkan bahwa metode baku tersebut harus direvisi

c. Penjaminan mutu yang mengindikasikan bahwa metode baku telah berubah seiring dengan berjalannya waktu

d. Metode baku digunakan dilaboratorium yang berbeda atau dikerjakan dengan alat yang berbeda

e. Untuk mendemonstrasikan kesetaraan antar 2 metode, seperti antara metode baru dan metode baku.

Parameter validasi yang ditetapkan pada penelitian ini antara lain: linearitas, Presisi, Akurasi, Limit of detection (LOD), Limit of Quantitation (LOQ) (Alwi, 2017)

Linieritas merupakan kemampuan suatu metode untuk memperoleh hasil-hasil uji yang secara langsung 
proporsional dengan konsentrasi analit pada kisaran yang diberikan. Konsentrasi dari sampel di dalam larutan bisa ditentukan dengan mengukur absorban pada panjang gelombang tertentu dengan menggunakan hukum LambertBeer. Hukum Lambert-Beer (Beer`s law) adalah hubungan linearitas antara absorban dengan konsentrasi larutan sampel. Linieritas suatu metode merupakan ukuran seberapa baik kurva kalibrasi yang menghubungkan antara respon (Y) dengan konsentrasi $(\mathrm{X})$. Linieritas dapat diukur dengan melakukan pengukuran tunggal pada konsentrasi yang berbeda-beda. Data yang diperoleh selanjutnya diproses dengan metode kuadrat terkecil, untuk selanjutnya dapat ditentukan nilai kemiringan (Slope), intersep, dan koefisien korelasinya. (Rohman, 2007: 469). Koefisien korelasi (r) adalah suatu ukuran hubungan linier antara dua set data. (Tahid \& Julia, 2017). Berdasarkan hukum Lambert-Beer, rumus yang digunakan untuk menghitung banyaknya cahaya yang hamburkan, dan absorbansi dinyatakan dengan rumus:

$$
\begin{aligned}
& \mathrm{T}=\frac{\mathrm{I}_{\mathrm{t}}}{\mathrm{I}_{0}} \quad \text { atau } \quad \% \mathrm{~T}=\frac{\mathrm{I}_{\mathrm{t}}}{\mathrm{I}_{0}} \times 100 \% \\
& \mathrm{~A}=-\log \mathrm{T}=-\log \frac{\mathrm{I}_{\mathrm{t}}}{\mathrm{I}_{0}}
\end{aligned}
$$

dimana I0 merupakan intensitas cahaya datang dan It atau I1 adalah intensitas cahaya setelah melewati sampel. Rumus yang diturunkan dari Hukum Beer dapat ditulis sebagai:

$$
A=\mathbf{a} \cdot \mathbf{b} \cdot \mathbf{c} \text { atau } A=\varepsilon \cdot b \cdot c
$$

Dimana, $\mathrm{A}=$ absorbansi, $\mathrm{b}$ atau terkadang digunakan $\mathrm{l}=$ tebal larutan (tebal kuvet diperhitungkan juga umumnya $1 \mathrm{~cm}$ ) $\mathrm{c}=$ konsentrasi larutan yang diukur, $\varepsilon=$ tetapan absorptivitas molar (jika konsentrasi larutan yang diukur dalam molar), a = tetapan absorptivitas (jika konsentrasi larutan yang diukur dalam ppm).

Metode Linier Square Regression digunakan karena terdapat hubungan linier antara nilai input dan nilai isyarat (respon). Hubungan ini dinyatakan sebagai :

$$
y=b x+a
$$

dimana $\mathrm{a}=$ Intercept (konstanta intercept yang merupakan titik potong antara garis regresi dengan sumbu y pada koordinat kartesius, $\mathrm{b}=$ Slope/kemiringan dari garis $\mathrm{y}=$ variabel terikat, $\mathrm{x}=$ variabel bebas.

Presisi (ketelitian) merupakan kedekatan antara hasil pengujian individu dalam serangkaian pengukuran terhadap suatu contoh homogen yang dilakukan pengambilan contoh secara berganda menurut prosedur yang telah ditetapkan (Alwi, 2017). Pada saat awal validasi metode seringkali hanya menggunakan 2 parameter pertama yaitu keterulangan dan presisi antara. Reprodusibilitas biasanya dilakukan ketika akan melakukan uji banding antar laboratorium (Gandjar dan rohman, 2009).

Pengujian presisi pada saat awal validasi metode seringkali hanya menggunakan 2 parameter yaitu: keterulangan dan presisi antara. Reprodusibilitas biasanya dilakukan ketika akan melakukan uji banding antar laboratorium (Rohman, 2007: 465).
Tabel 1. Perbandingan Konsentrasi Analit dengan Presisi (Hube L, Inc. Germany. 2003: 341)

\begin{tabular}{|l|l|l|l|}
\hline $\begin{array}{l}\text { Analit } \\
(\%)\end{array}$ & $\begin{array}{l}\text { Rasio } \\
\text { analit }\end{array}$ & Unit & RSD (\%) \\
\hline 100 & 1 & $100 \%$ & $<1,3$ \\
\hline 10 & $10-1$ & $10 \%$ & $<1,8$ \\
\hline 1 & $10-2$ & $1 \%$ & $<2,7$ \\
\hline 0,1 & $10-3$ & $0,1 \%$ & $<3,7$ \\
\hline 0,01 & $10-4$ & $100 \mathrm{ppm}$ & $<5,3$ \\
\hline 0,001 & $10-5$ & $10 \mathrm{ppm}$ & $<7,3$ \\
\hline 0,0001 & $10-6$ & $1 \mathrm{ppm}$ & $<11$ \\
\hline 0,00001 & $10-7$ & $100 \mathrm{ppb}$ & $<15$ \\
\hline 0,000001 & $10-8$ & $10 \mathrm{ppb}$ & $<21$ \\
\hline 0,0000001 & $10-9$ & $1 \mathrm{ppb}$ & $<30$ \\
\hline
\end{tabular}

Sumber: Husber L. Validation of Analytical Metods and Processes.

Akurasi (Kecermatan) adalah ukuran yang menunjukkan derajat kedekatan hasil analis dengan kadar analit yang sebenarnya. Kecermatan dinyatakan sebagai persen perolehan kembali (recovery) analit yang ditambahkan. Kecermatan hasil analis sangat tergantung kepada sebaran galat sistematik di dalam keseluruhan tahapan analisis. Oleh karena itu untuk mencapai kecermatan yang tinggi hanya dapat dilakukan dengan cara mengurangi galat sistematik tersebut seperti menggunakan peralatan yang telah dikalibrasi, menggunakan pereaksi dan pelarut yang baik, pengontrolan suhu, dan pelaksanaannya yang cermat, taat asas sesuai prosedur (Harmita, 2004).

Kecermatan ditentukan dengan dua cara yaitu metode simulasi (spiked-placebo recovery) atau metode penambahan baku (standard addition method). Dalam metode simulasi, sejumlah analit bahan murni (senyawa pembanding kimia CRM atau SRM) ditambahkan ke dalam campuran bahan pembawa sediaan farmasi (plasebo) lalu campuran tersebut dianalisis dan hasilnya dibandingkan dengan kadar analit yang ditambahkan (kadar yang sebenarnya). Dalam metode penambahan baku, sampel dianalisis lalu sejumlah tertentu analit yang diperiksa ditambahkan ke dalam sampel dicampur dan dianalisis lagi. Selisih kedua hasil dibandingkan dengan kadar yang sebenarnya (hasil yang diharapkan). Dalam kedua metode tersebut, persen peroleh kembali dinyatakan sebagai rasio antara hasil yang diperoleh dengan hasil yang sebenarnya. (Harmita, 2004).

Pengujian akurasi dapat dihitung melalui \% perolehan kembali (\% recovery) dengan rumus:

$$
\% \text { recovery }=\frac{\left(c_{p}-c_{\Lambda}\right)}{c^{*}{ }_{\Lambda}}
$$

Keterangan :

$\mathrm{Cp}=$ Konsentrasi sampel

$\mathrm{C}=$ Konsentrasi sampel sebenarnya

$\mathrm{C}=$ Konsentrasi Baku yang ditambahkan 
Tabel 2. Perbandingan Konsentrasi Analit dengan Akurasi (Hube L, Inc. Germany. 2003: 341) Sumber: Husber L. Validation of Analytical Metods and Processes)

\begin{tabular}{|l|l|l|l|}
\hline $\begin{array}{c}\text { Analit } \\
\text { pada } \\
\text { matriks } \\
\text { sampel } \\
\mathbf{( \% )}\end{array}$ & $\begin{array}{c}\text { Rasio } \\
\text { analit }\end{array}$ & \multicolumn{1}{|c|}{ Unit } & $\begin{array}{c}\text { Rata-rata } \\
\text { perolehan } \\
\text { kembali } \\
\text { (\%) }\end{array}$ \\
\hline 100 & 1 & $100 \%$ & $98-102$ \\
\hline$\leq 10$ & $10-1$ & $10 \%$ & $98-102$ \\
\hline$\leq 1$ & $10-2$ & $1 \%$ & $97-103$ \\
\hline$\leq 0,1$ & $10-3$ & $0,1 \%$ & $95-105$ \\
\hline 0,01 & $10-4$ & $100 \mathrm{ppm}$ & $90-107$ \\
\hline 0,001 & $10-5$ & $10 \mathrm{ppm}$ & $80-110$ \\
\hline 0,0001 & $10-6$ & $1 \mathrm{ppm}$ & $80-110$ \\
\hline 0,00001 & $10-7$ & $100 \mathrm{ppb}$ & $80-110$ \\
\hline 0,000001 & $10-8$ & $10 \mathrm{ppb}$ & $60-115$ \\
\hline 0,0000001 & $10-9$ & $1 \mathrm{ppb}$ & $40-120$ \\
\hline
\end{tabular}

Batas Deteksi dan Batas Kuantitasi, Batas deteksi adalah jumlah terkecil analit dalam sampel yang dapat dideteksi yang masih memberikan respon signifikan dibandingkan dengan blangko. Batas deteksi merupakan parameter uji batas. Batas kuantitasi merupakan parameter pada analisis renik dan diartikan sebagai kuantitas terkecil analit dalam sampel yang masih dapat memenuhi kriteria cermat dan seksama (Harmita, 2004). Limit Of Detection dan Limit Of Quantitation ditentukan dengan mengukur respon blanko 10 kali lalu dihitung simpangan baku respon blangko dan rumus yang digunakan adalah:

$$
\begin{aligned}
& L O D=3 \times \frac{s y f x}{n} \\
& L O Q=10 \times \frac{s y f x}{n}
\end{aligned}
$$

Flavonoid adalah kelompok senyawa bioaktif yang banyak ditemukan pada bahan makanan yang berasal dari tumbuhan. Flavonoid serupa dengan antioksidan, yang memiliki beragam manfaat untuk tubuh Anda, seperti dapat memperbaiki sel yang rusak akibat radikal bebas. Senyawa flavonoid adalah suatu kelompok fenol yang terbesar yang ditemukan di alam. Senyawa-senyawa ini merupakan zat warna merah, ungu dan biru dan sebagai zat warna kuning yang ditemukan dalam tumbuh-tumbuhan (Alwi, 2017).

Flavonoid disebut sebagai "respon biologis pengubah alami" yang telah dibuktikan secara eksperimental pada kemampuannya untuk memodifikasi reaksi tubuh terhadap virus, karsinogen, dan menunjukkan anti-alergi, antiinflamasi, anti-mikroba dan anti-kanker (Harborne, 1996).

Beberapa metode ekstraksi dapat dilakukan untuk mengisolasi flavonoid dari tanaman, seperti maserasi, refluks, sokletasi, dan sonikasi. Maserasi adalah metode ekstraksi yang paling mudah, murah dan cukup efektif serta mencegah kerusakan ekstrak yang biasanya dapat terjadi pada ekstraksi dengan metode panas. Namun, maserasi mempunyai kelemahan, yaitu waktu ekstraksi yang cukup lama dan kebutuhan pelarut yang cukup tinggi. Oleh karena itu, pada penelitian ini ekstraksi flavonoid dilakukan dengan metode Microwave-Assisted Extraction (MAE), yaitu modifikasi dari metode maserasi dengan adanya pemanasan gelombang mikro guna mempersingkat waktu ekstraksi, menurunkan kebutuhan pelarut, dan meningkatkan efektivitas proses ekstraksi. Gelombang mikro memanaskan dan menguapkan air sel bahan sehingga sel mengalami swelling, meregang dan pecah (Calinesu et. al., 2001). Akibatnya, analit sampel mudah untuk keluar dan terekstrak oleh pelarut. Menurut Desai dan Parikh (2015), MAE merupakan proses ekstraksi dengan pemanasan singkat menggunakan pelarut dalam jumlah yang lebih sedikit, sehingga lebih efisien, rendah energi dan ramah lingkungan. Selain itu, MAE merupakan metode ekstraksi yang lebih efektif dibandingkan maserasi karena menghasilkan rendemen senyawa yang lebih tinggi (Rafiee et. al., 2011).

Analisis TFC dilakukan dengan metode kolorimetri alumunium klorida yang absorbansinya diukur pada panjang gelombang $430 \mathrm{~nm}$, prinsip Penetapan Kadar Flavonoid adalah terjadinya pembentukan kompleks antara aluminium klorida dengan gugus keto pada atom C-4 dan gugus hidroksi pada atom C-3 atau C-5 yang bertetangga dari golongan flavon dan flavonol (Dyah dkk., 2014). Jumlah kandungan total senyawa flavonoid dilakukan analisis kuantitatif yaitu dengan metode pereaksi AlCl3 secara spektrofotometri UVVis dan kadarnya dinyatakan sebagai \% Quercetin Equivalent (QE). Senyawa yang digunakan sebagai standar pada penetapan kadar flavonoid ini adalah quersetin, karena quersetin merupakan flavonoid golongan flavonol yang memiliki gugus keto pada atom C-4 dan juga gugus hidroksil pada atom C-3 dan C-5 yang bertetangga (Dyah dkk., 2014).

Perhitungan kandungan flavonoid total menggunakan rumus berikut : (Shinta dkk, 2018)

Total Flavonoid : (c x V x fp) / m
Keterangan :
c : konsentrasi kesetaraan kuersetin $(\mathrm{mg} / \mathrm{L})$
$\mathrm{V}$ : volume ekstrak yang digunakan (L)
fp : faktor pengenceran
$\mathrm{m}$ : massa sampel $(\mathrm{g})$

TFC diintepretasikan sebagai miligram Quercetin Equivalent per gram dry weight (mg QE/g dw) sampel. Quercetin adalah flavonoid yang tersebar luas di alam. Nama quercetin digunakan semenjak tahun 1857, dan berasal dari kata quercetum (hutan ek).[2][3] Flavonol ini merupakan inhibitor pengangkut auksin polar yang muncul secara alami. Flavanoid merupakan golongan senyawa yang banyak ditemui dalam tumbuhan sebagai bahan obat. Salah satu contoh golongan flavonoid adalah kuercetin yang bersifat sebagai anti tumor. Kuercetin adalah senyawa golongan flavonol (bagian dari flavonoid) yang banyak terkandung dalam buah-buahan dan sayuran, misalnya apel, anggur, teh, bawang merah, dan kopi. Kuercetin memiliki 5 gugus $-\mathrm{OH}$ bebas yang dapat disubstitusi oleh gugus asil melalui reaksi esterifikasi. Ester kuercetin dengan mereaksikan kuercetin dengan senyawa golongan asam karboksilat, halida asam karboksilat, dan anhidrida karbolsilat. Untuk pengukuran larutan standar, masing-masing konsentrasi di-treatment dengan prosedur yang sama dengan pada pengukuran sampel.<smiles>O=c1c(O)c(-c2ccc(O)c(O)c2)oc2cc(O)cc(O)c12</smiles> 


\begin{tabular}{|c|c|}
\hline \multicolumn{2}{|l|}{ Nama } \\
\hline \multicolumn{2}{|c|}{$\begin{array}{l}\frac{\text { Nama IUPAC }}{2-(3,4-\text { dihydroxyphenyl)-3,5,7-trihydroxy- } 4 H \text { - }} \\
\text { chromen-4-one }\end{array}$} \\
\hline \multicolumn{2}{|l|}{ Sifat } \\
\hline$\underline{\text { Rumus kimia }}$ & $\mathrm{C}_{15} \mathrm{H}_{10} \mathrm{O}_{7}$ \\
\hline$\underline{\text { Massa molar }}$ & $302.236 \mathrm{~g} / \mathrm{mol}$ \\
\hline Penampilan & bubuk kristalin kuning ${ }^{[1]}$ \\
\hline$\underline{\text { Densitas }}$ & $1.799 \mathrm{~g} / \mathrm{cm}^{3}$ \\
\hline Titik lebur & $316^{\circ} \mathrm{C}$ \\
\hline$\frac{\text { Kelarutan }}{\text { dalam air }}$ & $\begin{array}{l}\text { Tidak larut dalam air; larut dalar } \\
\text { larutan alkalin encer }{ }^{[1]}\end{array}$ \\
\hline
\end{tabular}

Pereaksi AlCl3, Prinsip penetapan kadar flavonoid metode aluminium klorida adalah terjadinya pembentukan kompleks antara aluminium klorida dengan gugus keto pada atom C-4 dan gugus hidroksi pada atom C-3 atau C-5 yang bertetangga dari golongan flavon dan flavonol.

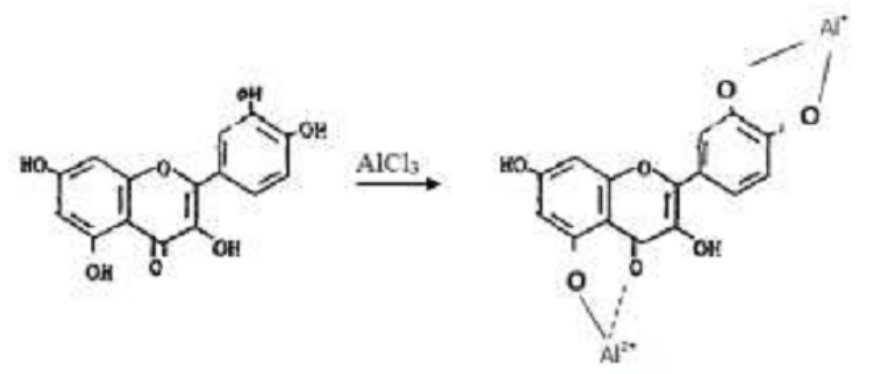

Gambar 2. Pembentukan senyawa kompleks quersetin-alumunium klorida

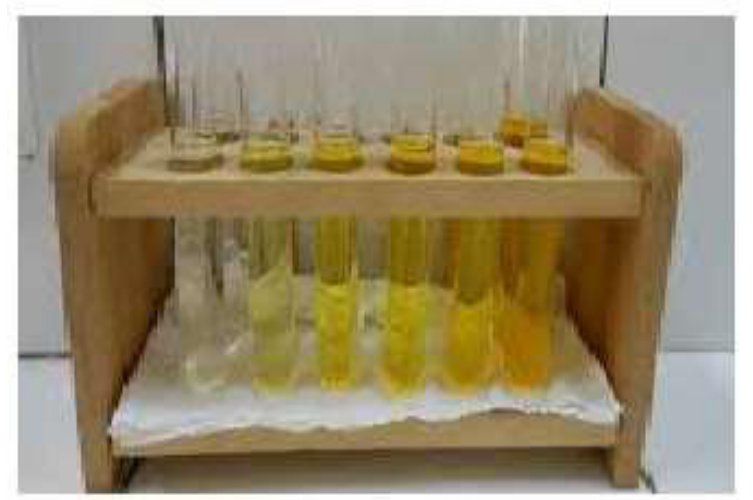

Gambar 3. Warna Senyawa Flavonoid berbagai konsentrasi

Spektrofotometri UV-Vis adalah pengukuran panjang gelombang dan intensitas sinar ultraviolet dan cahaya tampak yang diabsorbsi oleh sampel. Sinar ultraviolet dan cahaya tampak memiliki energi yang cukup untuk mempromosikan elektron pada kulit terluar ke tingkat energi yang lebih tinggi. Spektroskopi UV-Vis biasanya digunakan untuk molekul dan ion anorganik atau kompleks di dalam larutan. Spektrum UVVis mempunyai bentuk yang lebar dan hanya sedikit informasi tentang struktur yang bisa didapatkan dari spektrum ini sangat berguna untuk pengukuran secara kuantitatif. Sinar ultraviolet berada pada panjang gelombang 200-400 nm, sedangkan sinar tampak berada pada panjang gelombang 400-800nm. Absorpsi spektrofotometri UV-Vis adalah istilah yang digunakan ketika radiasi ultraviolet dan cahaya tampak diabsorpsi oleh molekul yang diukur.

Alatnya disebut spektrofotometer UV-Vis. Spektrofotometer UV-Vis (Ultra Violet-Visible) adalah salah satu instrumen yang digunakan dalam menganalisa suatu senyawa kimia.

Spektrofotometer digunakan karena kemampuannya dalam menganalisa banyak senyawa kimia serta kepraktisannya dalam hal preparasi sampel apabila dibandingkan dengan beberapa metode analisa (Herliani, 2008). Konsentrasi dari sampel di dalam larutan bisa ditentukan dengan mengukur absorban pada panjang gelombang tertentu dengan menggunakan hukum LambertBeer. Hukum Lambert-Beer (Beer's law) adalah hubungan linearitas antara absorban dengan konsentrasi larutan sampel.

Sumber cahaya dipergunakan untuk pengukuran absorpsi. Sumber cahaya ini harus memancarkan sinar dengan kekuatan yang cukup untuk penentuan dan pengukuran, juga harus memancarkan cahaya berkesinambungan yang berarti harus mengandung semua panjang gelombang dari daerah yang dipakai. Kekuatan sinar radiasi harus konstan selama waktu yang diperlukan. Sumber Cahaya Tampak yang paling umum dipakai adalah lampu Wolfram. Sedangkan sumber radiasi Ultra-violet biasa dipergunakan lampu Hidrogen atau Deuterium yang terdiri dari tabung kaca dengan jendela dari kwartz yang mengandung Hidrogen dengan tekanan tinggi. Oleh karena kaca menyerap radiasi Ultra-violet, maka sistim optik Spektrofotometer Ultra-Violet dan sel harus dibuat dari bahan kwartz.

Monokromator dipergunakan untuk me-misahkan radiasi ke dalam komponen-komponen panjang gelombang dan dapat memisahkan bagian spektrum yang diinginkan dari lainnya. Sel absorpsi dipakai dari bahan silika, kuvet dan plastik banyak dipakai untuk daerah Sinar Tampak. Kualitas data absorbans sangat tergantung pada cara pemakaian dan pemeliharaan sel. Sidik jari, lemak atau pengendapan zat pengotor pada dinding sel akan mengurangi transmisi. Jadi sel-sel itu harus bersih sekali sebelum dipakai (GLASSTON 1960; PECSOK et al. 1976; SKOOG \& WEST 1971).

Detektor dipergunakan untuk menghasil-kan signal elektrik. Dimana signal elektrik ini sebanding dengan cahaya yang diserap. Sig-nal elektrik ini kemudian dialirkan ke alat pengukur (GLASSTON 1960; PECSOK et al. 1976; SKOOG \& WEST 1971). Rekorder dipergunakan untuk mencatat data hasil pengukuran dari detektor, yang dinyatakan dengan angka.

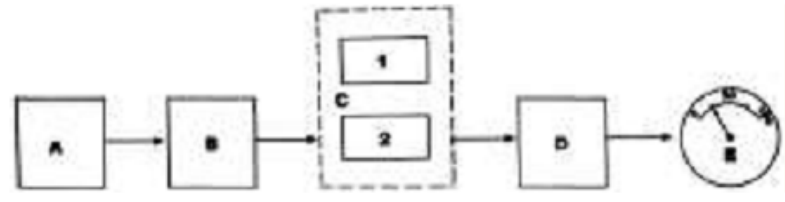

Gambar 4. Bagan susunan alat Spektrofotometer Ultra-violet dan Sinar Tampak.

Keterangan :
A : Sumber Cahaya
C2 : Pelarut
B : Monokromator
D : Detektor
C : Sel Absorbsi (tempat E : Recorder
larutan)
C1 : Contoh

Absorbansi yang terbaca pada spektrofotometer hendaknya antara 0,2 sampai 0,6. Anjuran ini berdasarkan 
anggapan bahwa pada kisaran nilai absorbansi tersebut kesalahan fotometrik yang terjadi adalah paling minimal (Gandjar dan Rohman, 2007)

Analisis Kuantitatif, Penggunaan utama spektrofotometri ultraviolet adalah dalam analisis kuantitatif. Apabila dalam alur spektrofotometer terdapat senyawa yang mengabsorpsi radiasi, akan terjadi pengurangan kekuatan radiasi yang mencapai detektor. Parameter kekuatan energi radiasi khas yang diabsorpsi oleh molekul adalah absorban (A) yang dalam batas konsentrasi rendah nilainya sebanding dengan banyaknya molekul yang mengabsorpsi radiasi dan merupakan dasar analisis kuantitatif. Penentuan kadar senyawa organik yang mempunyai gugus khromofor dan mengabsorpsi radiasi ultraviolet-sinar tampak, penggunaannya cukup luas. Konsentrasi kerja larutan analit umumnya 10 sampai $20 \mu \mathrm{g} / \mathrm{ml}$, tetapi untuk senyawa yang nilai absorptivitasnya besar dapat diukur pada konsentrasi yang lebih rendah. Senyawa yang tidak mengabsorpsi radiasi ultraviolet-sinar tampak dapat juga ditentukan dengan spektrofotometri ultraviolet-sinar tampak, apabila ada reaksi kimia yang dapat mengubahnya menjadi khromofor atau dapat disambungkan dengan suatu pereaksi khromofor (Satiadarma, 2004).

\section{Metode Penelitian}

\section{Alat yang digunakan \\ 1. Spectrofotometer UV-VIS \\ 2. Labu ukur \\ 3. Mikropipet \& Tip pipet \\ 4. Gelas Kimia \\ 5. Botol Vial dan Eppendorf}

\section{Neraca Analitik \\ 7. Centrifuge mikro \\ 8. Kuvet \\ 9. Incubator \\ 10. Beaker Glass}

Bahan

1. Aquadest

2. Ethanol

3. Reagent $\mathrm{AlCl} 3$

4. Kuercetin

\section{A. Prosedur dan Skema Kerja}

Pembuatan Larutan Standar Kuercetin

- Ditimbang Kuercetin 1 gram

- Ditambahkan Aquadest hingga 1000 ml pada labu ukur

- Didapatkan larutan induk dengan konsentrasi 1000 ppm

\section{Preparasi Sampel}

- Sejumlah sampel daun kering dihaluskan/ditumbuk

- Kemudian dimaserasi dengan methanol selama 3

- hari, dilakukan sonifikasi

- Dicentrifuge

- Kemudian diperoleh supernatant / ekstraknya

Penentuan Panjang Gelombang yang mempunyai Serapan Maximum

- Dipilih salah satu konsentrasi kuercetin, kemudian dilakukan preparasi dengan ditambahkan ethanol $4 \mathrm{ml}$ dan $1 \mathrm{ml}$ larutan $\mathrm{AlCl} 3 \mathrm{Di}$ vortex

- $\quad$ Didiamkan selama \pm 30 menit

- Kemudian diukur serapannya dengan spektrofotometer uv/vis pada panjang gelombang 400-500 nm dengan menggunakan blangko.
Dari larutan induk diatas dibuat dengan beberapa konsentrasi kuercetin 2-14 ppm

- Kemudian dilakukan preparasi dengan ditambahkan ethanol $4 \mathrm{ml}$ dan $1 \mathrm{ml}$ larutan $\mathrm{AlCl} 3$ Di vortex

Didiamkan selama \pm 30 menit

- Kemudian diukur serapannya dengan spektrofotometer uv/vis pada panjang gelombang nm yang sudah ditentukan.

- Kemudian dibuat kurva kalibrasi hubungan antara absorbansi dan konsentrasi

\section{B. UJI PRESISI}

- Dipipet sejumlah larutan sampel dengan volume sama, dilakukan sebanyak 6 buah

- Kemudian dilakukan preparasi dengan ditambahkan ethanol $4 \mathrm{ml}$ dan $1 \mathrm{ml}$ larutan $\mathrm{AlCl} 3 \mathrm{Di}$ vortex

Didiamkan selama \pm 30 menit

- Kemudian diukur serapannya dengan spektrofotometer $\mathrm{uv} / \mathrm{vis}$ pada panjang gelombang $\mathrm{nm}$ yang sudah ditentukan.

- Absorbansi sampel yang dihasilkan diplot kan pada kurva kalibrasi

- Dihitung konsentrasi flavonoid dalam sampel

- Dihitung Presisi, SD dan RSD nya

- Dibandingkan RSD yang dihasilkan dengan RSD

- Horwitz (Metode Reproducibility)

\section{UJI \% RECOVERY}

- Dipipet sejumlah larutan sampel dengan volume sama, kemudian ditambahkan sejumlah larutan standar kuercetin, dilakukan sebanyak 6 buah

- Kemudian dilakukan preparasi dengan ditambahkan ethanol $4 \mathrm{ml}$ dan $1 \mathrm{ml}$ larutan $\mathrm{AlCl} 3$ Di vortex

- Didiamkan selama \pm 30 menit

- Kemudian diukur serapannya dengan spektrofotometer $\mathrm{uv} / \mathrm{vis}$ pada panjang gelombang $\mathrm{nm}$ yang sudah ditentukan.

- Absorbansi sampel yang dihasilkan diplot kan pada kurva kalibrasi

- Dihitung konsentrasi flavonoid dalam sampel+standar

- $\quad$ Hitung \% Recovery nya

\section{Uji Limit Deteksi}

- Di pipet sejumlah tetes larutan standar, dilakukan sebanyak $10 \mathrm{bh}$

- Kemudian dilakukan preparasi dengan ditambahkan ethanol $4 \mathrm{ml}$ dan $1 \mathrm{ml}$ larutan $\mathrm{AlCl} 3 \mathrm{Di}$ vortex

- Didiamkan selama \pm 30 menit

- Kemudian diukur serapannya dengan spektrofotometer uv/vis pada panjang gelombang $\mathrm{nm}$ yang sudah ditentukan.

- Dihitung nilai rata-rata konsentrasi, SD dan RSD (RSD harus besar atau fluktuatif)

\section{E. Uji Limit Kuantisasi}

- Dibuat larutan dengan konsentrasi sebesar (ratarata+5SD) dan (rata-rata+7SD) dari hasil pengukuran LOD. 
- Dan seterusnya dikerjakan seperti penentuan Presisi diatas, dilakukan sebanyak 10 bh Dihitung nilai rata-rata konsentrasi, SD dan RSD Limit Kuantisasi RSD harus kecil

\section{B. Skema kerja}

Skema kerja untuk prosedur di atas dapat dilihat pada gambar berikut :

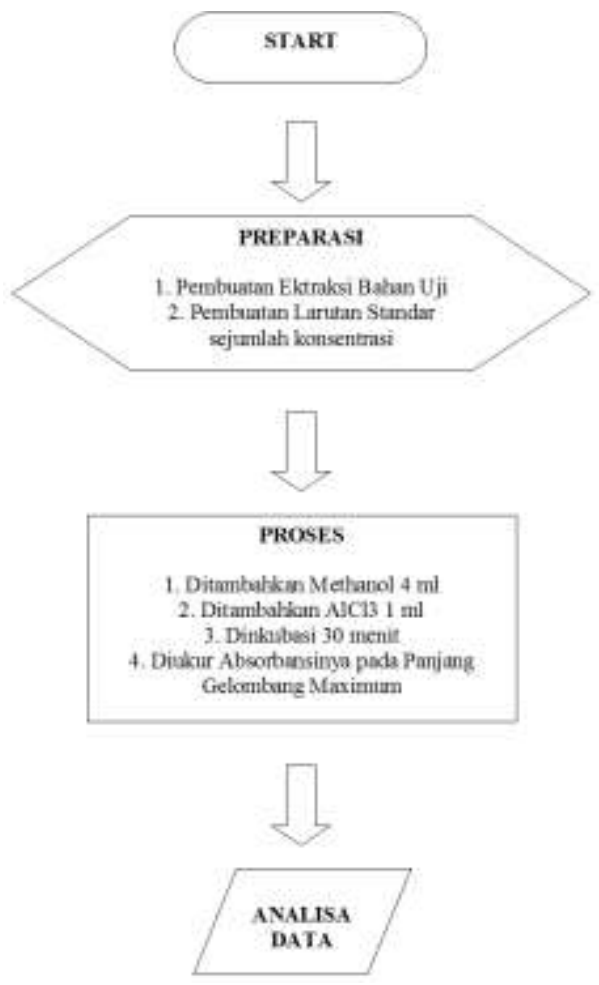

\section{HASIL dAN PEMbahasan}

A. Penentuan Panjang Gelombang yang mempunyai Serapan Maximum

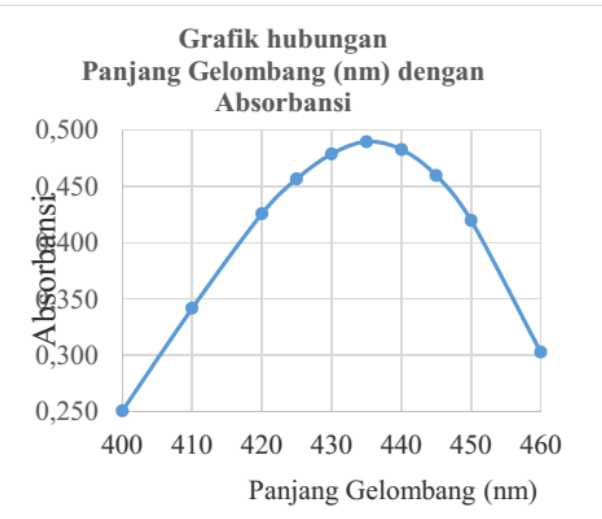

Gambar 5. Grafik Hubungan Panjang Gelombang (nm) dengan Absorbansi

Dipilih salah satu dari larutan standar Kuercetin untuk menentukan panjang gelombang yang mempunyai Absorbansi maksimum dimulai dari $400 \mathrm{~nm}$ sampai dengan $460 \mathrm{~nm}$. Dari Grafik hubungan antara Panjang Gelombang dengan Absorbansi didapatkan panjang gelombang yang mempunyai Absorbansi Maximum pada 435,0 nm dengan absorbansi paling tinggi 0,490.
Gambar 6. Kurva Kalibrasi TFC Kuercetin Equivalen

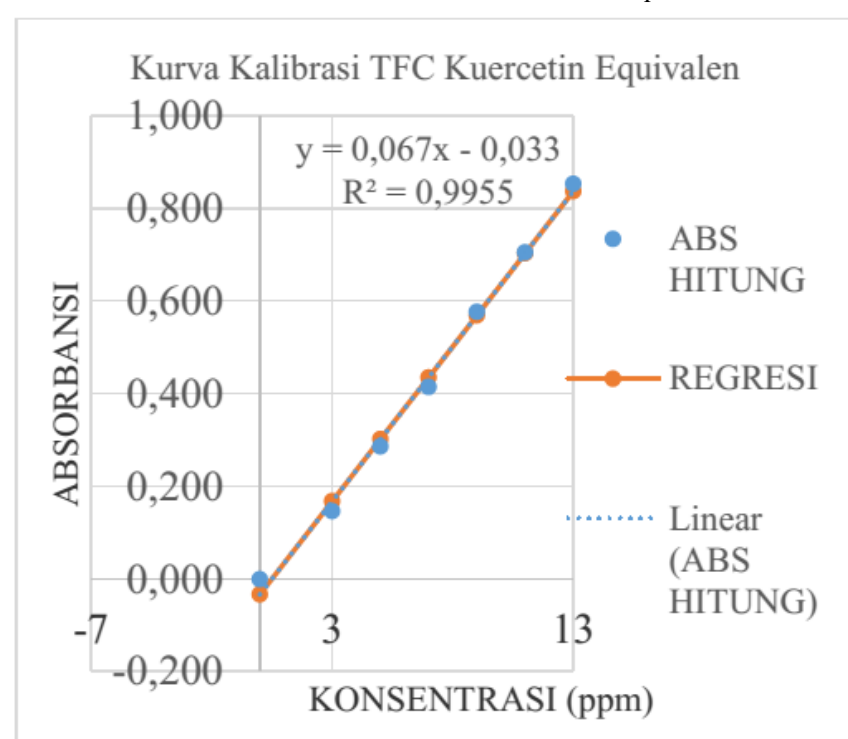

Pada Pengujian Linieritas, Linieritas dikatakan baik karena Koefisien Korelasi mendekati 1 (R2 mendekati 1) yaitu menunjukkan angka 0,9955 . Slope menunjukkan respon yang proposional yang diberikan oleh detektor terhadap input dan output. Dengan dihasilkan persamaan regeresi : $\mathrm{y}=0,067 \mathrm{x}-0,033$

\section{Pengujian Presisi}

Pada Panjang Gelombang 435,0 nm.

$\begin{array}{ccccc}\text { ABS 1 } & \text { ABS 2 } & \text { ABS 3 } & \begin{array}{c}\text { ABS } \\ \text { rata2 }\end{array} & \text { C (PPM) } \\ 0,312 & 0,310 & 0,303 & 0,308 & 5,098 \\ 0,315 & 0,310 & 0,310 & 0,312 & 5,147 \\ 0,325 & 0,321 & 0,321 & 0,322 & 5,307 \\ 0,314 & 0,304 & 0,310 & 0,309 & 5,113 \\ 0,340 & 0,314 & 0,304 & 0,319 & 5,262 \\ 0,305 & 0,296 & 0,297 & 0,299 & 4,963\end{array}$

Pada pengujian Presisi, Presisi dikatakan baik karena nilai RSD lebih kecil dari pada CV Horwitz yang dinyatakan dalan Reproducubility Metode. Nilai RSD adalah 2,40 \% sedangkan nilai CV Horwitz sebesar 12,50 \%.

\section{Pengujian \% Recovery}

Pengukuran Absorbansi rata-rata Spiking Pada Panjang Gelombang 435,0 nm.

$\begin{array}{rrrc}\text { ABS 1 } & \text { ABS 2 } & \text { ABS 3 } & \begin{array}{c}\text { ABS } \\ \text { RERATA }\end{array} \\ 0,340 & 0,342 & 0,342 & \mathbf{0 , 3 4 1} \\ 0,347 & 0,346 & 0,346 & \mathbf{0 , 3 4 6} \\ 0,355 & 0,357 & 0,357 & \mathbf{0 , 3 5 6} \\ 0,342 & 0,342 & 0,342 & \mathbf{0 , 3 4 2} \\ 0,350 & 0,353 & 0,353 & \mathbf{0 , 3 5 2} \\ 0,333 & 0,333 & 0,333 & \mathbf{0 , 3 3 3}\end{array}$


Jurnal Teknik: Ilmu dan Aplikasi Vol. 08 No. 1, Januari 2020

\begin{tabular}{ccccc}
\hline $\mathbf{p p m})$ & $\mathbf{p p m}$ & $\mathbf{p p m}$ & $\mathbf{p p m}$ & $\mathbf{A - B} / \mathbf{C}$ \\
0,341 & 5,591 & 5,098 & 0,500 & 98,570 \\
0,346 & 5,665 & 5,147 & 0,500 & 103,548 \\
0,356 & 5,815 & 5,307 & 0,500 & 101,557 \\
0,342 & 5,600 & 5,113 & 0,500 & 97,574 \\
0,352 & 5,750 & 5,262 & 0,500 & 97,574 \\
0,333 & 5,466 & 4,963 & 0,500 & 100,561 \\
& & & \\
AVERAGE (RECOVERY) \% & & 99,897 \\
\hline \multicolumn{5}{l}{ SD (RECOVERY) \% } \\
\hline \multicolumn{7}{l}{ MEAN RECOVERY \% } \\
\hline
\end{tabular}

Pada pengujian Akurasi dengan metode \% Recovery penambahan Larutan Standar, dengan Recovery dapat diterima karena konsentrasi Spiking 0,5 ppm dengan ratarata \% Recovery 99,89\% (berkisar $80-110 \%$.

\section{Pengujian LOD}

Pengujian Limit Deteksi, pada Panjang Gelombang 435,0 nm.

$\begin{array}{ccccc}\text { ABS 1 } & \text { ABS } & \text { ABS } & \text { ABS } & \text { C (ppm) } \\ 0,009 & 0,010 & 0,015 & 0,011 & 0,66 \\ 0,009 & 0,015 & 0,015 & 0,013 & 0,69 \\ 0,045 & 0,045 & 0,040 & 0,043 & 1,14 \\ 0,053 & 0,053 & 0,040 & 0,049 & 1,22 \\ 0,095 & 0,098 & 0,097 & 0,097 & 1,94 \\ 0,087 & 0,087 & 0,087 & 0,087 & 1,79 \\ 0,030 & 0,002 & 0,002 & 0,011 & 0,66 \\ 0,020 & 0,018 & 0,019 & 0,019 & 0,78 \\ 0,050 & 0,045 & 0,045 & 0,047 & 1,19 \\ 0,034 & 0,056 & 0,057 & 0,049 & 1,22\end{array}$

\begin{tabular}{lc} 
AVERAGE (C) PPM & 1,13 \\
\hline SD (PPM) & 0,46 \\
\hline RSD / CV (\%) & 40,39 \\
\hline CV HORWITZ (\%) & 15,71 \\
\hline LOD (ppm) & 1,37 \\
\hline
\end{tabular}

Dari hasil pengujian dihasilkan LOD diterima karena respon menunjukkan nilai Fluktuatif dan tidak ada nilai 0 , kemudian ditunjukkan dengan nilai RSD lebih besar dari pada CV Horwitz 40,39>15,71). LOD diterima sebesar 1,37 ppm.

\section{Pengujian LOQ}

Pengujian Limit Quantity

Pada Panjang Gelombang 435,0 nm

$\begin{array}{lllll}0,046 & 0,047 & 0,047 & 0,047 & 1,190 \\ 0,040 & 0,040 & 0,040 & 0,040 & 1,090 \\ 0,039 & 0,039 & 0,043 & 0,040 & 1,095 \\ 0,045 & 0,045 & 0,050 & 0,047 & 1,190 \\ 0,037 & 0,037 & 0,038 & 0,037 & 1,050 \\ 0,041 & 0,041 & 0,042 & 0,041 & 1,110 \\ 0,040 & 0,040 & 0,040 & 0,040 & 1,090 \\ 0,047 & 0,047 & 0,040 & 0,045 & 1,160 \\ 0,039 & 0,039 & 0,043 & 0,040 & 1,095 \\ 0,045 & 0,045 & 0,041 & 0,044 & 1,145\end{array}$

Dari hasil pengujian dihasilkan LOQ diterima karena respon menunjukkan nilai yang hampir presisi dan ditunjukkan dengan nilai RSD lebih kecil dari pada CV Horwitz $(4,60<15,73)$ LOQ diterima dengan sebesar 0,516 ppm.

\section{KESIMPULAN DAN SARAN}

\section{A. Kesimpulan}

Validasi metode analisa TFC dinyatakan diterima/valid dengan 5 parameter :

1. Kurva Kalibrasi Kuercetin pada pengujian Linieritas dinyatakan diterima/Valid, dengan nilai koefisien korelasi 0,9955 (mendekati 1)

2. Pada Pengujian Presisi, Presisi diterima/valid menggunakan metode Reproducbility dengan nilai RSD lebih kecil dari pada CV Horwitz $(2,40 \%<12,50 \%)$

3. Hasil Pengujian Recovery diterima dengan hasil rata-rata Recovery $99,89 \%$

4. Batas Deteksi diterima sebesar 1,37 ppm

5. Batas Kuantisasi diterima sebesar 0,516 ppm

B. Saran

1. Perlunya dilakukan validasi metode analisa Total Flavonoid Content / TFC secara berkala, juga terhadap metode analisa antioksidan yang lain.

\section{DAfTAR Pustaka}

[1] Alwi, Heriati. 2017. Validasi Analisis Flavanoid dari Ekstrak Etanol Kasumba Turate (Carthamus tinctorius L.) secara Spectrofotometri UV-Vis. Makasar:UIN Alauddin Makasar

[2] Azizah, Dyah Nur., Kumolowati, Endang., Faramayuda, Fahrauk. 2014. Penetapan Kadar Flavonoid Metode AlCl3 pada Ekstrak Metanol Kulit Buah Kako (Theobroma caco L.) Universitas Jendral Achmad Yani

[3] Amin I., Norazaidah Y., Hainida KIE. 2006. Antioxidant Activity and Fenolic Content of Rau and Balched Amarantus Spesies Food Chem, 94, 47-52.

[4] Bhaigyabati, T., T, Kirithika., J, Ramya., K, Usha. 2011. Phytochemical constituens and Antioxidant Activity of Various Extracts Of Corn Silk (Zea mays. L). Research Journal of Pharmaceutical, Biological and Chemical Sciences. 2(4):986993

[5] Calinescu I., Ciuculescu C., Popescu M., Bajanaru S., Epure G., 2001, Microwaves Assisted Extraction of Active Principles from Vegetal Material, Romanian International Conference on Chemistry and Chemical Engineering, 12, 1-6.

[6] Desai, M.A., Parikh, J., 2015. Extraction of essential oil from leaves of lemon grass using microwave radiation: optimization, comparative, kinetic, and biological studies. ACS Sustainable Chem. Eng. 3, 421-431.
ABS 1
ABS 2
ABS 3
ABS
RERATA
(ppm) 
[7] Gandjar, Gholib., dan Rohman, 2009. Kimia Farmasi Analisis. Pustaka Pelajar: Yogyakarta.

[8] GLASSTON, S. 1960. Text book of physical chemistry. $2^{\text {nd }}$ ed. Macmillan and Co. Ltd., London.

[9] Harborne, J.B. 1996. Metode Fitokimia. Penuntun Cara Modern Menganalisis Tumbuhan. Alih Bahasa Kosasih Padmawinata. ITB. Hlm. 35-50.

[10] Harmita, 2004. Petunjuk Pelaksanaan Validasi Metode dan Cara Perhitungannya. Majalah Ilmu Kefarmasian, Vol. I, No.3, Desember 2004.

[11] Herliani, A. 2008. Spectrofotometri. Pengendalian Mutu Agro Industri. Program D4-PJJ

[12] https://id.wikipedia.org/wiki/Quercetin

[13] https://priyambodo1971.wordpress.com/cpob/kualif ikasi-danvalidasi-paradigma-baru/pengertian-dan-jenis-jenis-validasi/

[14] L, Silva., BR, Pezzini., L, Soares., 2009. Spectrofotometric determination of the total flavonoid content in Ocimum silicum L. (Lamiaceae) leaves. Phcog Mag, 11:96-101

[15] Rafiee, Z., Jafari, Alami, Khomeiri, M., 2011, Microwave Assisted Extraction of Phenolic Compounds from Olive Leaves; A Comparison with Maceration, J. Animal and Plant Sci., 21(4):738-745.

[16] Rohman, A. Kimia Farmasi Analisis. Yogyakarta: Pustaka Pelajar 2007

[17] Sandhar, HK., B Kumar., S Prasher., P Tiwari., M Salham, P Sharma. 2011. A Review of Phitochemistry and Pamacology og Flavanoid, Internasional Pharmaceutica Siencia, 1 (1), 2541

[18] Sinta R. Dewi, Naily Ulya, Bambang D. Argo, 2018. Kandungan Flavonoid dan Aktivitas Antioksidan Ekstrak Pleurotus ostreatus. Malang:Universitas Brawijaya

[19] Sutiadarma. Analisis Struktur Organik secara Spektroskopi. Yogyakarta: UGM Press. 2004

[20] Tahid dan Julia Kantasubrata. 2017. Tinjauan Umum Validasi Spectrofotometer UV/Vis. Bandung : RC Chem Learning Centre

[21] Winarsi, Hery. 2007. Antioksidan Alami dan Radikal Bebas. Yogyakarta: Kanisius. 